\title{
Formulation of a Gluten-free Cookie with Prebiotics and an Edible Cover Enriched with Probiotics
}

\author{
Stephany Chávez ${ }^{1 \mathbb{D}}$, Raul Rodriguez-Herrera ${ }^{1, *} \mathbb{D}$, Sonia Silva ${ }^{1 \mathbb{D}}$, Sendar Nery ${ }^{1 \mathbb{D}}$, Carolina \\ Flores $^{1}$ (D), Xochitl Ruelas 2 (D) \\ 1 Department of Food Research, Faculty of Chemical Sciences, Autonomous University of Coahuila, Boulevard Venustiano \\ Carranza and José Cárdenas S / n, Republica Oriente, C.P. 25280, Saltillo, Coahuila, Mexico; \\ yesenia_silva@uadec.edu.mx (S.S.), sendar_nery@uadec.edu.mx (S.N.), carolinaflores@uadec.edu.mx (C.F.); \\ 2 Department of Food Science and Technology, Antonio Narro Autonomous Agrarian University; \\ xochitlruelas@uadec.edu.mx (X.R.); \\ * Correspondence: raul.rodriguez@uadec.edu.mx (R.R.H.);
}

Scopus Author ID 55996458500

Received: 3.07.2021; Revised: 15.08.2021; Accepted: 18.08.2021; Published: 4.09.2021

\begin{abstract}
Gluten-free foods are products that have become relevant today due to the prevalence of diseases related to the consumption of gluten proteins. This study developed a gluten-free cookie based on buckwheat flour and corn, reduced in fat with symbiotic properties. Several formulations were tested, the best cookies were selected based on texture, color, and sensory. The five most significant samples were evaluated using a hedonic test. Subsequently, the two samples that showed a higher score in the hedonic scale on color and texture parameters were selected. The two formulations were covered with a film-forming solution enriched with probiotics. No significant differences were shown for both cookies related to preference or texture by the panelists. The caloric intake and fat content were lower in formulation two. While formulation one has a greater contribution of fiber and protein. According to the Oficial Mexican regulations, the formulations presented an adequate microbiological quality in the period ( 4 weeks) and evaluated conditions $\left(35^{\circ} \mathrm{C}\right.$ with $70 \%$ relative humidity). Despite this time, the attributes of color and texture were affected after the storage period, finding significant differences between the cookies and time.
\end{abstract}

Keywords: intestinal inflammation; irritable bowel; allergies; food intolerances.

(C) 2021 by the authors. This article is an open-access article distributed under the terms and conditions of the Creative Commons Attribution (CC BY) license (https://creativecommons.org/licenses/by/4.0/).

\section{Introduction}

Currently, there is a growing demand for gluten-free products, which is a consequence of the incidence of diseases related to gluten proteins [1]. The most effective treatment is based on a gluten-free diet, which translates into a great interest in developing these foods [2]. Developing new functional gluten-free bakery foods represents a challenge for the food industry because of the technological limitations. In addition to the nutritional contribution and the characteristic sensory attributes of these foods. It is also known that the market for glutenfree products is one of the most favorable markets in the food industry, so the formulation of these foods with functional ingredients such as fiber, antioxidants, and probiotics have recently acquired a great interest in the population [3]. Gluten-related pathologies are classified as food allergy; affecting 0.2 to $0.5 \%$ of the world population [4], celiac disease (CD), with a prevalence of 0.1 to $1.6 \%$ worldwide [5], and gluten sensitivity, with an approximate incidence of $6 \%$ for the US population [6]. 
For this reason, researchers are looking for gluten-free sources to be used for the development of new products. It is estimated that the market for gluten-free products will increase from 4.18 billion dollars in 2017 to 6.47 billion dollars in 2023 [1]. Among the glutenfree products with the highest consumption worldwide are bread and cookies [7]. Using as sources of flour cereals that are considered gluten-free such as rice (Oryza sativa), corn (Zea mays), sorghum (Sorghum), and a range of pseudo-cereals such as buckwheat (Fagopyrum esculentum), amaranth (Amaranthus), and quinoa (Chenopodium quinoa) [8, 9].

Cookies represent a baked product composed mainly of three ingredients: flour, fat, and sugar [10]. In the global market, cookies were valued at $\$ 30.6$ billion in 2018, and growth of $5.3 \%$ is expected each year (Grand View Research, Cookie Market Size, Share and Trends Analysis Report, 2019-2025). For the elaboration of these products, different combinations between cereals and pseudo-cereals have been investigated. One of the pseudo-cereals studied is buckwheat, which has gained popularity due to its beneficial potential for health, providing a good amino acid profile, vitamins, minerals, and fiber [11, 12], and a high amount of polyphenols and flavonoids such as rutin, catechin, myricetin, isoquercitrin, and anthocyanins $[13,14]$.

On the other hand, one of the aspects that have become a trend in the food industries is edible films, which refer to biopolymer structures in thin layers that can be consumed and applied on the surface of food $[15,16]$. The use of this type of biofilm has prolonged the useful life of food by showing a barrier effect that retards the mobility of water vapor and oxygen [17, 18]. In addition, it has also been reported that they can serve as vehicles for active compounds such as probiotics in food systems and inhibit the growth of pathogens and improve microbiota health [19-21]. Probiotics have been shown to improve health in the diseases mentioned above [22]. In the present work, a gluten-free cookie with a coating enriched with probiotics was developed. In addition, sensory attributes, nutritional contribution, and shelf life of the best formulations were evaluated.

\section{Materials and Methods}

\subsection{Raw materials.}

The materials used to develop the gluten-free cookie were buckwheat flour from Arrowhead mills (USA), cornflour from Maseca (Mexico), inulin from Enature (Mexico), jocoque from La Vaquita (Mexico), blueberries, agave honey from Tía Ofilia (Mexico), LALA butter (Mexico) and a coated one made up of whey protein, glycerin from Deiman (Mexico), sodium alginate from Sigma Chemical Company (USA) and the probiotic strain L. brevis.

\subsection{Cookie formulation.}

Based on a completely randomized experimental design with a factorial arrangement, the ratio between buckwheat flour and corn was determined, and inulin and jocoque were used as a fat substitute. $60 \%$ of the total fat was replaced, reported in the literature as the most conventional to maintain the organoleptic attributes. The mixtures are shown in Table 1 . The other ingredients were added in the same amounts for all groups. 
Table 1. Completely randomized experimental design with factorial arrangement, for the elaboration of a gluten-free cookie with the fat substitute.

\begin{tabular}{|c|c|}
\hline$\%$ Buckwheat and cornflour & \% Inulin and jocoque as a fat substitute \\
\hline \multirow{3}{*}{$\begin{array}{l}\text { Treatment } 1 \\
(60 \mathrm{HB}+40 \mathrm{HC})\end{array}$} & $\mathrm{A}(60 \mathrm{IN}+40 \mathrm{~J})$ \\
\hline & $\mathrm{B}(50 \mathrm{IN}+50 \mathrm{~J})$ \\
\hline & $\mathrm{C}(40 \mathrm{IN}+60 \mathrm{~J})$ \\
\hline \multirow{3}{*}{$\begin{array}{l}\text { Treatment } 2 \\
(65 \mathrm{HB}+35 \mathrm{HC})\end{array}$} & $\mathrm{A}(60 \mathrm{IN}+40 \mathrm{~J})$ \\
\hline & $\mathrm{B}(50 \mathrm{IN}+50 \mathrm{~J})$ \\
\hline & $\mathrm{C}(40 \mathrm{IN}+60 \mathrm{~J})$ \\
\hline \multirow{3}{*}{$\begin{array}{l}\text { Treatment } 3 \\
(70 \mathrm{HB}+30 \mathrm{HC})\end{array}$} & $\mathrm{A}(60 \mathrm{IN}+40 \mathrm{~J})$ \\
\hline & $\mathrm{B}(50 \mathrm{IN}+50 \mathrm{~J})$ \\
\hline & $\mathrm{C}(40 \mathrm{IN}+60 \mathrm{~J})$ \\
\hline \multirow{3}{*}{$\begin{array}{l}\text { Treatment } 4 \\
(75 \mathrm{HB}+25 \mathrm{HC})\end{array}$} & $\mathrm{A}(60 \mathrm{IN}+40 \mathrm{~J})$ \\
\hline & $\mathrm{B}(50 \mathrm{IN}+50 \mathrm{~J})$ \\
\hline & $\mathrm{C}(40 \mathrm{IN}+60 \mathrm{~J})$ \\
\hline \multirow{3}{*}{$\begin{array}{l}\text { Treatment } 5 \\
(80 \mathrm{HB}+20 \mathrm{HC})\end{array}$} & $\mathrm{A}(60 \mathrm{IN}+40 \mathrm{~J})$ \\
\hline & $\mathrm{B}(50 \mathrm{IN}+50 \mathrm{~J})$ \\
\hline & $\mathrm{C}(40 \mathrm{IN}+60 \mathrm{~J})$ \\
\hline
\end{tabular}

Where HB: Buckwheat Flour, HC: Corn Flour, IN: Inulin and J: Jocoque.

Five groups of cookies were obtained with a total of three treatments per group. The cookies were subjected to texture and color tests, obtaining the five most representative samples to be subsequently subjected to a hedonic sensory test.

\subsubsection{Colour.}

The formulations were subjected to colorimetry analysis using a colorimeter. The CIE$\mathrm{L} * \mathrm{a} * \mathrm{~b} *$ system was used (luminosity $=\mathrm{L} * \mathrm{a} *=$ red $/$ green, $\mathrm{b} *=$ yellow $/$ blue). Three measurements were made for each sample, and the results were averaged.

\subsubsection{Texture.}

The firmness parameter was determined using an XT Plus Texture Analyzer. Following the AACC 74- Protocol 09 [23] standard. The adjustment procedure in the texture analyzer was as follows: compression force measurement mode; test speed: $1.0 \mathrm{~mm} / \mathrm{s}$; pre-test speed: 1.0 $\mathrm{mm} / \mathrm{s}$; post-test speed: $10.0 \mathrm{~mm} / \mathrm{s}$; distance: $4.0 \mathrm{~mm}$. The firmness was determined, expressed as the maximum force $(\mathrm{F})$ at the breaking point. Three measurements were made for each sample, and the results were averaged.

\subsubsection{Sensory analysis.}

The sensory evaluation was carried out with 29 semi-trained judges from the Antonio Narro Autonomous Agrarian University in the Sensory Evaluation laboratory of the Food Science and Technology Department. The best five formulations coded with three random numbers were evaluated based on the intensity of the attributes of global appearance, color, odor, texture, taste, and global acceptance. The attributes were rated using a hedonic scale with 7 points $(1=$ very unpleasant while $7=$ very pleasant) [24]. A completely randomized block design was used for the experiment. The results were analyzed with the statistical package Infostat version 2018 applying a Friedman test, and in the event of a significant difference, the LSD test was performed for means comparison. Then, the best two formulations were selected.

\subsection{Probiotic enriched coating formulation.}

2.3.1. Preparation of the L. brevis strain. 
Ten $\mu \mathrm{L}$ of the L. brevis strain were inoculated in $10 \mathrm{~mL}$ of MRS broth for 16 hours at $37^{\circ} \mathrm{C}$ in anaerobiosis. The final broth was transferred under aseptic conditions to sterile $2 \mathrm{~mL}$ Eppendorf tubes to be centrifuged at $5000 \mathrm{rpm}$ for 5 minutes at $4^{\circ} \mathrm{C}$. Subsequently, it was standardized to a final concentration of $10^{\wedge} 9 \mathrm{CFU} / \mathrm{mL}$ using the McFarland scale [19].

2.3.2. Cookie formulation with a probiotic enriched coating.

A film-forming solution was prepared with sodium alginate in $1 \% \mathrm{w} / \mathrm{w}$, whey of milk protein in $2 \% \mathrm{w} / \mathrm{w}$, and glycerol in $5 \% \mathrm{w} / \mathrm{w}$ in distilled water, mixing at room temperature and subjected to heating for 10 minutes at a temperature of $80^{\circ} \mathrm{C}$, constantly stirring, to allow complete hydration and eliminate residual microflora. Afterward, the film-forming solution was allowed to cool to a temperature of $25^{\circ} \mathrm{C}$ to be later inoculated with the L. brevis strain. Three pellets corresponding to $6 \mathrm{~mL}$ of culture broth were inoculated into $20 \mathrm{~mL}$ of the filmforming solution [25]. The film-forming solution and the probiotics were placed on the selected formulations and allowed to dry at $25^{\circ} \mathrm{C}$ for one hour.

\subsubsection{Color and texture.}

Selected formulations were subjected to colorimetry analysis using a colorimeter. The CIE-L $* \mathrm{a} * \mathrm{~b} *$ system was used (luminosity $=\mathrm{L} * \mathrm{a} *=$ red / green, $\mathrm{b} *$ = yellow / blue). Measurements were made in triplicate. The firmness parameter was determined using an XT Plus Texture Analyzer using the same parameters mentioned above.

\subsubsection{Sensory analysis.}

The two cookies with the probiotic-enriched coating were placed on a five-point hedonic scale $(1=\mathrm{I}$ didn't like it while $5=\mathrm{I}$ loved it $)$ with a panel of 30 consumers. The attributes evaluated were the global appearance, color, smell, texture, flavor, and global acceptance [24]. The results obtained were analyzed with the Infostat version 2018 statistical package applying a Kruskal-Wallis test.

\subsection{Physicochemical properties and shelf life of the selected cookies.}

\subsubsection{Proximal analysis.}

The proximal composition of the two selected cookies was determined by the methods proposed by the Association of Official Analytical Chemists (AOAC) [26]. The moisture content was determined by the difference between the weight of the dry sample and the grams of the sample used (Method 925.09). The ashes were determined by placing $2 \mathrm{~g}$ of dry sample in a crucible at constant weight in a muffle at $600^{\circ} \mathrm{C}$ for 3 hours. Determining the difference in weight (Method 923.03). The lipid content was determined by the Soxhlet method. After the extraction, it was placed in the oven at $100^{\circ} \mathrm{C}$ for 24 hours to calculate differences between the weights (Method 935.38). Crude protein was determined by the Kjeldahl method. In which nitrogen is converted to ammonium sulfate, using a conversion factor (5.70) (962.10). The carbohydrate content was calculated by difference, using the formula recommended by Camargo [27]. The determination of crude fiber under the AOAC methodology 962.09.

\subsubsection{Shelf life of selected cookies.}


The shelf life of the cookies was estimated under controlled conditions of temperature $\left(35^{\circ} \mathrm{C}\right)$ and humidity (70\% relative humidity) for 30 days. The parameters evaluated were the microbiological quality, texture, and color. The microbiological analysis was performed based on the Official Mexican Regulations [28]. Making dilutions from the sample and placing $10 \mathrm{~g}$ of the sample in $99 \mathrm{~mL}$ of phosphate buffer, mixing $1 \mathrm{~mL}$ of the primary dilution in $9 \mathrm{~mL}$ of the diluent to make serial dilutions from -1 to -6 . The aerobic mesophilic content [29], total coliforms [30], and molds and yeasts [31] were determined, each one with the marked specifications. A plate count was performed on the day of preparation (time 0 ) and at weeks 1 , 2,3 , and 4 [32].

For the evaluation of firmness, it was determined using an XT Plus Texture Analyzer. Using the same parameters mentioned above, taking data at time 0 and subsequent weeks 1,2, 3 , and 4 . While the colorimetry analysis was performed using a colorimeter. The CIE-L * a * $\mathrm{b} *$ system was used (luminosity $=\mathrm{L} *$, $\mathrm{a} *=$ red / green, $\mathrm{b} *=$ yellow / blue), during the mentioned times.

\section{Results and Discussion}

\subsection{Preliminary color and texture analysis.}

The elaboration of the gluten-free cookie was carried out based on a completely randomized experimental design with the factorial arrangement, obtaining 5 groups of cookies made up of three treatments each. Table 2 shows no significant difference ( $>0.05)$ between the groups for the attribute of firmness. However, groups 2 and 3 were the ones that showed higher firmness values. The texture is considered one of the most important attributes when making cookies. According to Altındağ [11], the firmness of cookies made with the mixture between corn flour and buckwheat is lower than other combinations. Another determining factor of the texture is sugar since it fulfills the function of giving structure and texture to the cookie because of recrystallization after cooling. However, sugar is a highly caloric component, so alternatives have been sought to replace it, as shown by $\mathrm{Xu}$ [1]. The replacement of conventional fat with inulin affected cookies texture, which is a soluble fiber, which absorbs water during the product elaboration; this explains the increased hardness and adhesiveness of the cookies [33-35]. Combining the different types of flour and inulin produced a cookie with less firmness than that reported in the literature and with greater grittiness. The colorimetry parameters did not show a significant difference in the values of $\mathrm{L}$ and $\mathrm{a} *$. At the $\mathrm{b} *$ value, the cookies in group 4 had a shade close to the green-blue color, resulting in a not very pleasant color for consumers. According to Evrim and Paciulli [36, 37], during the baking process, the Maillard reaction occurs when reducing sugars react with amino acids, producing compounds that influence the taste, smell, and color of food, which justifies the intensities of cookies brightness in this study and the increase in brown color.

Table 3 shows the composition of the cookies selected from each group based on texture and color parameters. The final dough had a distribution of $50 \%$ flour, $31 \%$ fat, and 18.5 sugar of the total weight.

\subsection{Sensory evaluation of the uncoated cookie.}

The first cookies sensory analysis was carried out to determine which formulations with the greatest acceptability for consumers, which would be subjected to application of the coating 
enriched with probiotics. Table 4 shows the results of the hedonic scale. Where cookie 2 is the one that received the highest scores in color, smell, appearance, and global acceptance, followed by cookie 3 . However, statistical analyses indicated no significant difference in the global appearance attribute, which indicates that the panelist did not appreciate differences among the cookies at first glance. Giménez [38] reported that in several studies, the cookies enriched with buckwheat flour had shown better scores for the acceptability attribute, which is verified in the preference results of cookies 2 , which within its composition has a higher proportion of buckwheat flour. Regarding the texture attribute, the highest value was given for cookies 5, in addition to showing a significant difference together with cookies 3 . There are reports that sensory acceptance can be affected by the addition of fiber in baked products. This is mainly related to appearance, texture, flavor, and loss of crunchiness [33]. Results suggested that the best cookies to place the coating were cookies 2 and 3 because of their high scores on the hedonic scale and texture tests.

\subsection{Color and texture of the coated cookies.}

The two selected cookies were coated with a probiotic-forming film. Changes between color and texture attributes were assessed. Table 5 shows that there is no significant difference between both cookies. Cookie 2 has a higher value. Regarding the colorimetry results, the values of $\mathrm{L}$ and $\mathrm{a} *$ do not show a significant difference. While the value of $\mathrm{b} *$ is higher in cookie 2 , which indicates green-blue tones. The $b *$ value has a significant difference between cookies. Transfer of water vapor between surface and environment is the factor that contributes to the distribution of moisture from cookies outside to inside [19], which could have caused changes in cookie texture when placing the coating. It can be seen that both cookies after coating had lower values compared to the first ones, which is supported by the firmness parameter since the coating confers moisture to the cookie structure, and this also affects color because of lipids oxidation. Reports are mentioning that, when forming a biofilm, the addition of bacteria increases the coating opacity. However, adding protein to the film-forming solution increased L values [39], coupled with increased opacity.

\subsection{Sensory evaluation of the coated cookie.}

The second sensory analysis yielded that statistically, no difference is perceived between both cookies for the tested attributes (global appearance, taste, smell, color, texture, and acceptability). Figure 1 shows the Principal Component Analysis of the cookies, highlighting that cookie 1 is characterized by greater flavor. On the other hand, cookie 2 has higher values for appearance, smell, texture, and acceptability.

\subsection{Proximal analysis of selected cookies.}

The proximal analysis of the two samples is shown in Table 6. Cookie 2 shows a lower caloric intake and lower fat and ash values. While cookie 1 stood out for providing a greater amount of protein and crude fiber. In the statistical analysis, a significant difference for protein between both cookies was showed. The cookie 1composition has a greater amount of buckwheat flour, which makes sense with the highest protein values. It is considered a pseudocereal with a good amino acid profile, main lysine as an essential amino acid [40, 41]. Regarding fiber, buckwheat has been studied numerous times, resulting in a high starch content 
(73.5\%). However, of that percentage, 33.5 corresponds to resistant starch, which confers it the fiber properties [42].

\subsection{Shelf life of selected cookies.}

The microbiological quality of cookies yielded negative results for the presence of aerobic mesophiles, total coliforms, fungus, and yeasts, following what is allowed by Official Mexican Regulations [32]. Temperature is a determining factor for the growth and metabolism of cells; as it increases, biochemical reactions accelerate. However, humidity is another parameter to consider since there are different ranges for the optimum of the analyzed microorganisms [43]. All values found at the storage end do not exceed the maximum permitted limit value suggested by the Official Mexican Regulations. So the cookie is suitable for human consumption. In Figure 2, the null growth was observed at week 4 of storage of aerobic mesophiles, total coliforms, fungi, and yeasts (in a dilution of $10^{\wedge}-6$ ).

On the other hand, cookie color and texture were modified throughout storage. The statistical analysis shows a significant difference between the values of $\mathrm{L}, \mathrm{a} *$, and $\mathrm{b}$ * between the two samples across time. On the other hand, for texture only a significant difference was shown among times and no for the different samples. It can be seen that texture value decreased as the storage time passed. The loss of hardness in this type of product is caused by moisture absorption. Water affects texture by softening [43]. At the same time, colorimetry shows changes from stored conditions. Showing higher L values, which indicates a higher degree of luminosity than the other two parameters $\mathrm{a} *$ and $\mathrm{b} *$. Demonstrating that the lighter colors are preferred by consumers, as reported by Sakač [44]. As the days passed, the values of a and $b$ increased, resulting in a darker cookie linked to compounds oxidation within the food matrix. Table 7 compares color and texture values between the cookie samples during 4 weeks.

Table 2. Attributes of firmness and color of the cookie groups.

\begin{tabular}{l|c|c|c|c} 
Cookies & Firmness & $\mathbf{L}$ & $\mathbf{a}^{*}$ & $\mathbf{b}^{*}$ \\
\hline Group 1 & $1.31 \pm 0.53^{a}$ & $45.69 \pm 1.70^{a}$ & $6.08 \pm 0.45^{a}$ & $19.81 \pm 1.41^{a b}$ \\
\hline Group 2 & $1.67 \pm 0.80^{a}$ & $46.82 \pm 2.75^{a}$ & $5.71 \pm 0.45^{a}$ & $18.81 \pm 1.78^{b}$ \\
\hline Group 3 & $1.85 \pm 1.04^{a}$ & $48.35 \pm 0.48^{a}$ & $6.29 \pm 0.43^{a}$ & $20.96 \pm 0.16^{a b}$ \\
\hline Group 4 & $1.50 \pm 0.91^{a}$ & $48.34 \pm 5.26^{a}$ & $6.55 \pm 0.60^{a}$ & $22.51 \pm 1.58^{a}$ \\
\hline Group 5 & $1.42 \pm 0.48^{a}$ & $47.06 \pm 0.34^{a}$ & $5.46 \pm 0.24^{a}$ & $18.82 \pm 0.71^{b}$
\end{tabular}

Table 3. Composition of dough for the selected cookies.

\begin{tabular}{l|l|l|l|l|l} 
\% Ingredients & Cookie 1 & Cookie 2 & Cookie 3 & Cookie 4 & Cookie 5 \\
\hline HC & 21 & 19 & 24 & 24 & 14 \\
\hline HB & 21 & 23 & 18 & 18 & 28 \\
\hline Jocoque & 7 & 8 & 8 & 9 & 7 \\
\hline Inulin & 9 & 8 & 8 & 7 & 9 \\
\hline Butter & 11 & 11 & 11 & 11 & 11 \\
\hline Agave honey & 15 & 15 & 15 & 15 & 15 \\
\hline Dehydrated cranberries & 15 & 15 & 15 & 15 & 15 \\
Where HB: Buckwheat Flour and HC: Corn Flour
\end{tabular}

Table 4. Sensory analysis of the selected cookies using a hedonic scale.

\begin{tabular}{|c|c|c|c|c|c|c|}
\hline \multirow[t]{2}{*}{ Treatment } & \multicolumn{6}{|c|}{ Attribute } \\
\hline & $\begin{array}{c}\text { Global } \\
\text { appearance }\end{array}$ & Colour & Odor & Texture & Taste & $\begin{array}{c}\text { Acceptance } \\
\text { global }\end{array}$ \\
\hline Cookie 1 & $2.91 \pm 1.46 \mathrm{a}$ & $2.67 \pm 1.19 \mathrm{ab}$ & $2.71 \pm 1.18 \mathrm{ab}$ & $2.83 \pm 1.55 \mathrm{abc}$ & $2.31 \pm 1.35 \mathrm{a}$ & $2.67 \pm 1.16 \mathrm{ab}$ \\
\hline Cookie 2 & $3.38 \pm 1.27 \mathrm{a}$ & $3.38 \pm 1.03 \mathrm{~b}$ & $4.00 \pm 1.05 \mathrm{e}$ & $2.69 \pm 1.46 \mathrm{ab}$ & $3.47 \pm 1.04 \mathrm{c}$ & $3.86 \pm 0.97 \mathrm{e}$ \\
\hline Cookie 3 & $3.03 \pm 1.58 \mathrm{a}$ & $2.66 \pm 0.91 \mathrm{a}$ & $3.05 \pm 0.80 \mathrm{bc}$ & $2.28 \pm 1.61 \mathrm{a}$ & $3.71 \pm 1.35 c$ & $3.00 \pm 1.08 \mathrm{abcd}$ \\
\hline Cookie 4 & $2.72 \pm 1.53 \mathrm{a}$ & $3.16 \pm 1.16 \mathrm{ab}$ & $2.19 \pm 1.02 \mathrm{a}$ & $3.19 \pm 1.61 \mathrm{bcd}$ & $2.36 \pm 1.30 \mathrm{ab}$ & $2.53 \pm 1.38 \mathrm{a}$ \\
\hline Cookie 5 & $2.95 \pm 1.45 \mathrm{a}$ & $3.14 \pm 0.95 \mathrm{ab}$ & $3.05 \pm 1.27 \mathrm{bcd}$ & $4.02 \pm 1.28 \mathrm{e}$ & $3.16 \pm 1.21 \mathrm{c}$ & $2.93 \pm 1.66 \mathrm{abc}$ \\
\hline
\end{tabular}


Table 5. Firmness and color parameters of coated cookies.

\begin{tabular}{l|c|c|c|c} 
& Firmness & $\mathbf{L}$ & $\mathbf{a}^{*}$ & $\mathbf{b}^{*}$ \\
\hline Cookie 1 & $1.963 \pm 0.68^{a}$ & $36.83 \pm 1.28^{a}$ & $6.23 \pm 0.39^{a}$ & $13.29 \pm 0.41^{a}$ \\
\hline Cookie 2 & $2.238 \pm 0.38^{a}$ & $38.24 \pm 0.97^{a}$ & $6.77 \pm 0.65^{a}$ & $15.21 \pm 0.57^{b}$
\end{tabular}

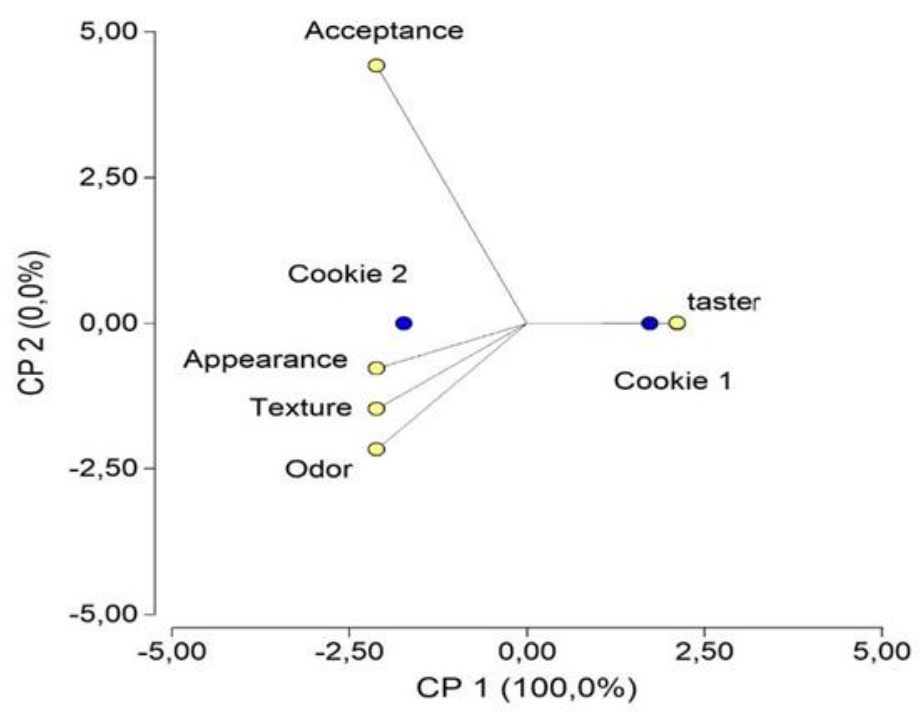

Figure 1. Principal components analysis of cookies 1 and 2.

Table 6. Proximal analysis of selected cookies.

\begin{tabular}{l|c|c|c|c|c|c} 
& \multicolumn{3}{|c|}{ Cookie 1 } & \multicolumn{3}{c}{ Cookie 2 } \\
\hline & Values (\%) & \% Wet base & Kcal per 100 g & Values (\%) & \% Wet base & Kcal per 100 g \\
\hline Moisture & 20.35 & & & 21.9 & & 17.28 \\
\hline $\begin{array}{l}\text { Protein by Kjeldahl } \\
(\text { Nx5.70) }\end{array}$ & 4.465 & 3.53 & 19.06 & 4.1 & 3.2 & 79.8 \\
\hline Soxhlet fat & 13.11 & 10.38 & 96.53 & 11 & 8.59 & \\
\hline Total ash & 2.06 & 1.63 & & 1.07 & 0.83 & \\
\hline $\begin{array}{l}\text { Carbs calculated by } \\
\text { difference }\end{array}$ & 59.54 & 47.1 & 193.11 & 61.3 & 47.8 & 195.98 \\
\hline Crude fiber & 2.42 & & & 2.28 & & \\
\hline Total kcal & & 308.7 & & & 293.06
\end{tabular}
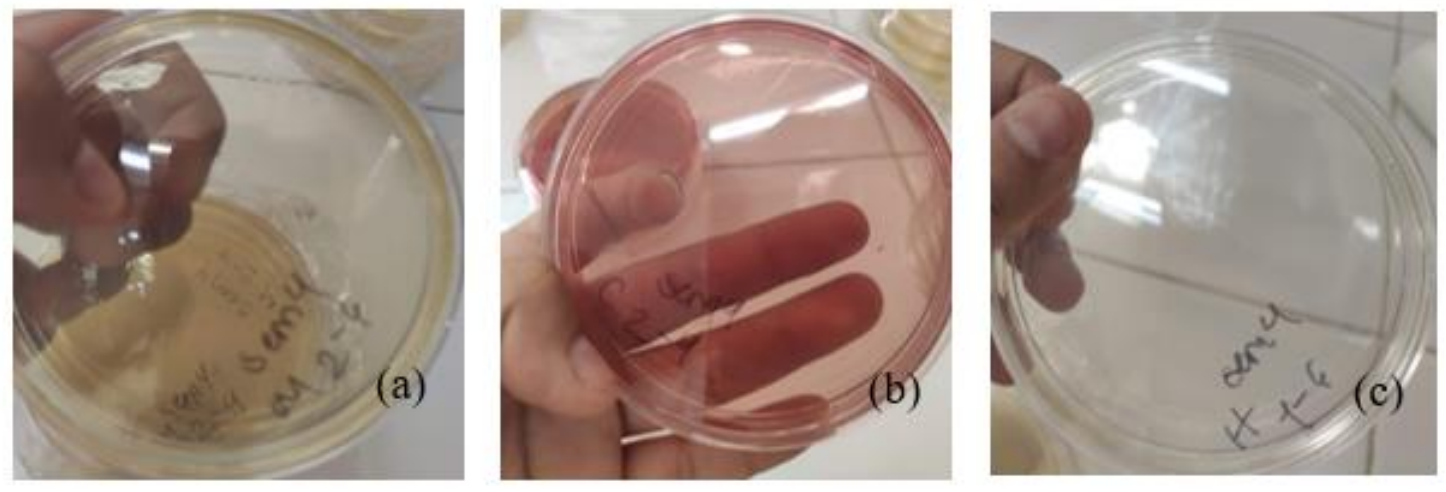

Figure 2. Images of $10^{\wedge}-6$ dilution plate plating week 4. (a) aerobic mesophyll growth, (b) total coliform growth, (c) fungal and yeast growth

Table 7. Texture and colorimetry for 4 weeks of the cookies stored at $35^{\circ} \mathrm{C}$ with $70 \%$ relative humidity.

\begin{tabular}{l|c|c|c|c|c} 
& & \multicolumn{3}{|c}{ Colour } & \\
\hline \multirow{3}{*}{ Cookie 1} & Weeks & $\mathbf{L}$ & $\mathbf{a}^{*}$ & $\mathbf{b}^{*}$ & Texture \\
\cline { 2 - 6 } & 1 & $33.65 \pm \mathbf{0 . 2 5}$ & $4.26 \pm 0.32$ & $12.59 \pm \mathbf{0 . 3 6}$ & $2.1566 \pm \mathbf{0 . 1 0}$ \\
\cline { 2 - 6 } & 2 & $36.83 \pm 1.57$ & $6.23 \pm \mathbf{0 . 4 7}$ & $13.29 \pm \mathbf{0 . 5 1}$ & $1.9636 \pm \mathbf{0 . 8 4}$ \\
\cline { 2 - 6 } & 3 & $38.11 \pm \mathbf{0 . 8 0}$ & $8.22 \pm \mathbf{0 . 4 6}$ & $17.88 \pm \mathbf{0 . 0 7}$ & $1.5223 \pm \mathbf{0 . 2 4}$ \\
\hline \multirow{2}{*}{ Cookie 2 } & 4 & $39.19 \pm 0.06$ & $10.2 \pm \mathbf{0 . 9 9}$ & $19.31 \pm \mathbf{0 . 2 9}$ & $1.067 \pm \mathbf{0 . 0 5}$ \\
\cline { 2 - 6 } & 2 & $35.06 \pm 0.33$ & $5.07 \pm \mathbf{0 . 1 6}$ & $14.05 \pm \mathbf{0 . 5 4}$ & $2.5663 \pm \mathbf{0 . 3 0}$ \\
\hline
\end{tabular}




\begin{tabular}{c|c|c|c|c|c} 
& \multicolumn{4}{|c|}{ Colour } & ( \\
\hline & Weeks & $\mathbf{L}$ & $\mathbf{a}^{*}$ & $\mathbf{b}^{*}$ & Texture \\
\hline & 3 & $39.84 \pm \mathbf{0 . 3 7}$ & $10.15 \pm \mathbf{0 . 1 2}$ & $21.64 \pm \mathbf{0 . 5 2}$ & $1.8996 \pm \mathbf{0 . 1 3}$ \\
\cline { 2 - 6 } & 4 & $42.3 \pm \mathbf{0 . 3 0}$ & $11.45 \pm \mathbf{0 . 3 8}$ & $24.28 \quad \pm \mathbf{0 . 2 7}$ & $1.378 \pm \mathbf{0 . 3 8}$
\end{tabular}

\section{Conclusions}

According to organoleptic attributes and coated with the film-forming solution enriched with probiotics, the two most outstanding cookies obtained similar scores in the sensory tests by panelists without having a significant difference in the sensory analysis, which indicates that the consumer has no preference over one or the other. Cookie 1 stood out in the flavor attribute, while cookie 1 obtained better values in the other attributes after being subjected to principal component analysis. Cookies did not significantly differ for moisture, ash, carbohydrates, and fat values in the proximal analysis. However, cookie 1 turned out to have a higher caloric intake with 308 calories per $100 \mathrm{~g}$ and a higher value of fat, protein, ash, and fiber. While cookie 2 has a lower caloric intake, providing 296 calories per $100 \mathrm{~g}$. According to the Official Mexican regulations, the different samples showed good microbiological quality, free of pathogen growth in a storage period of one month. However, cookies' texture and color were affected after the storage conditions $\left(35^{\circ} \mathrm{C}\right.$ and $70 \%$ relative humidity), showing a progressive decrease from the first week of storage, with a more notable firmness in cookie 1 . The values of $\mathrm{L}, \mathrm{a} *$, and $\mathrm{b} *$ increased as the days passed, with the appearance of darker colors in both cookies. No significant difference was observed between L and a values. Cookie 2 presented a greater intensity of the red hue with a significant difference in the value of $b *$.

\section{Funding}

This project did not receive external funding.

\section{Acknowledgments}

SNCG appreciates the financial support from the National Council of Science and Technology of Mexico (CONACyT) to carry out her postgraduate studies. This study was funded by the Autonomous University of Coahuila.

\section{Conflicts of Interest}

The authors declare no conflict of interest.

\section{References}

1. Xu, J.; Zhang, Y.; Wang, W.; Li, Y. Advanced properties of gluten-free cookies, cakes, and crackers: A review. Trends in Food Science \& Technology 2020, 103, 200-213, https://doi.org/10.1016/j.tifs.2020.07.017.

2. Rosell, C.M.; Barro, F.; Sousa, C.; Mena, M.C. Cereals for developing gluten-free products and analytical tools for gluten detection. Journal of Cereal Science 2014, 59, 354-364, http://doi.org/10.1016/j.jcs.2013.10.001.

3. Miranda, J.; Lasa, A.; Bustamante, M.A.; Churruca, I.; Simon, E. L. Nutritional Differences Between a Gluten-free Diet and a Diet Containing Equivalent Products with Gluten. Plant Foods for Human Nutrition 2014, 69, 182-187, http://doi.org/10.1007/s11130-014-0410-4.

4. Zuidmeer, L.; Goldhahn, K.; Rona, R.J.; Gislason, D.; Madsen, C.; Summers, C.; Sodergren, E.; Dahlstrom, J.; Lindner, T.; Sigurdardottir, S.T.; McBride, D.; Keil, T. The prevalence of plant food allergies: A systematic review. Journal of Allergy and Clinical Immunology 2008, 121, 1210-1218.-1214, http://doi.org/10.1016/j.jaci.2008.02.019. 
5. Abadie, V.; Sollid, L.M.; Barreiro, L.B.; Jabri, B. Integration of Genetic and Immunological Insights into a Model of Celiac Disease Pathogenesis. Annual Review of Immunology 2011, 29, 493-526, http://doi.org/10.1146/annurev-immunol-040210-092915.

6. Sapone, A.; Lammers, K.M.; Casolaro, V.; Cammarota, M.; Giuliano, M.T.; De Rosa, M.; Stefanile, R.; Mazzarella, G.; Tolone, C.; Russo, M.I.; Esposito, P.; Ferraraccio, F.; Cartenì, M.; Riegler, G.; de Magistris, L.; Fasano, A. Divergence of gut permeability and mucosal immune gene expression in two gluten-associated conditions: celiac disease and gluten sensitivity. BMC Medicine 2011, 9, 23, http://doi.org/10.1186/17417015-9-23.

7. Jnawali, P.; Kumar, V.; Tanwar, B. Celiac disease: Overview and considerations for development of glutenfree foods. Food Science and Human Wellness 2016, 5, 169-176, https://doi.org/10.1016/j.fshw.2016.09.003.

8. Pestorić, M.; Sakač, M.; Pezo, L.; Škrobot, D.; Nedeljković, N.; Jovanov, P.; Šimurina, O.; Mandić, A. Physicochemical characteristics as the markers in predicting the self-life of gluten-free cookies. Journal of Cereal Science 2017, 77, 172-179, https://doi.org/10.1016/j.jcs.2017.08.013.

9. Brites, L.; Ortolan, F.; Silva, D.W.d.; Bueno, F.R.; Rocha, T.S.; Chang, Y.; Steel, C.J.F.S.; International, T. Gluten-free cookies elaborated with buckwheat flour, millet flour and chia seeds. Food Science and Technology 2019, 39, 458-466.

10. Tumbas Šaponjac, V.; Ćetković, G.; Čanadanović-Brunet, J.; Pajin, B. S.; Djilas, S.; Petrović, J.; Lončarević, I.; Stajčić, S.; Vulić, J. Sour cherry pomace extract encapsulated in whey and soy proteins: Incorporation in cookies. Food Chemistry 2016, 207, 27-33, http://dx.doi.org/10.1016/j.foodchem.2016.03.082.

11. Altındağ, G.; Certel, M.; Erem, F.; İlknur Konak, Ü. Quality characteristics of gluten-free cookies made of buckwheat, corn, and rice flour with/without transglutaminase. Food Sci Technol Int 2014, 21, 213-220, http://doi.org/10.1177/1082013214525428.

12. Ozturk, O.K.; Mert, B. The effects of microfluidization on rheological and textural properties of gluten free corn breads. Food Research International 2018, 105, 782-792, http://doi.org/10.1016/j.foodres.2017.12.008.

13. Li, J.; Hossain, M.S.; Ma, H.; Yang, Q.; Gong, X.; Yang, P.; Feng, B. Comparative metabolomics reveals differences in flavonoid metabolites among different coloured buckwheat flowers. Journal of Food Composition and Analysis 2020, 85, 103335, https://doi.org/10.1016/j.jfca.2019.103335.

14. Różańska, M.B.; Siger, A.; Szwengiel, A.; Dziedzic, K.; Mildner-Szkudlarz, S. Maillard Reaction Products in Gluten-Free Bread Made from Raw and Roasted Buckwheat Flour. Molecules 2021, 26, https://doi.org/10.3390/molecules26051361.

15. Wittaya, T. Edible films and coatings: Characteristics and properties. International Food Research Journal 2008, 15, 237-248.

16. Bersaneti, G.T.; Garcia, S. V.; Mali, S.; Pedrine Colabone Celligoi, M.A. Evaluation of the prebiotic activities of edible starch films with the addition of nystose from Bacillus subtilis natto. LWT 2019, 116, https://doi.org/10.1016/j.lwt.2019.108502.

17. Falguera, V.; Quintero Cerón, J.P.; Jiménez, A.; Muñoz, J.A.; Ibarz, A. Edible films and coatings: Structures, active functions and trends in their use. Trends in Food Science \& Technology 2011, 22, 292-303, https://doi.org/10.1016/j.tifs.2011.02.004.

18. Ashwini, A.; Ramya, H.N.; Ramkumar, C.; Reddy, K.R.; Kulkarni, R.V.; Abinaya, V.; Naveen, S.; Raghu, A.V. Reactive mechanism and the applications of bioactive prebiotics for human health: Review. Journal of Microbiological Methods 2019, 159, 128-137, https://doi.org/10.1016/J.MIMET.2019.02.019.

19. Soukoulis, C.; Yonekura, L.; Gan, H. H.; Behboudi-Jobbehdar, S.; Parmenter, C. J.; Fisk, I. Probiotic edible films as a new strategy for developing functional bakery products: The case of pan bread. Food Hydrocolloids 2014, 39, 231-242, https://doi.org/10.1016/j.foodhyd.2014.01.023.

20. Neffe-Skocińska, K., Rzepkowska, A., Szydłowska, A., \& Kołożyn-Krajewska, D. Trends and Possibilities of the Use of Probiotics in Food Production. Alternative and Replacement Foods. 2018; pp. 65-94, https://doi.org/10.1016/b978-0-12-811446-9.00003-4.

21. Putta, S.; Yarla, N.S.; Lakkappa, D.B.; Imandi, S.B.; Malla, R.R.; Chaitanya, A.K.; Chari, B.P.V.; Saka, S.; Vechalapu, R.R.; Kamal, M.A.; Tarasov, V.V.; Chubarev, V.N.; Siva Kumar, K.; Aliev, G. Chapter 2 Probiotics: Supplements, Food, Pharmaceutical Industry. In: Therapeutic, Probiotic, and Unconventional Foods. Grumezescu, A.M.; Holban, A.M. Eds.; Academic Press: 2018; 2, pp.15-25, https://doi.org/10.1016/B978-0-12-814625-5.00002-9.

22. Farias, D.d.P.; de Araújo, F.F.; Neri-Numa, I.A.; Pastore, G.M. Prebiotics: Trends in food, health and technological applications. Trends in Food Science \& Technology 2019, 93, 23-35, https://doi.org/10.1016/j.tifs.2019.09.004.

23. AACC. American Association of Cereal Chemistry. Approved methods of analysis of the AACC (10th ed.). St Paul, 2014.

24. Anzaldúa Morales, A. La evaluación sensorial de los alimentos en la teoría y la práctica 1984. Facultad de ciencias químicas. Universidad Autónoma de Chihuahua, México.

25. Odila Pereira, J.; Soares, J. C.; J.P. Monteiro, M.; Gomes, A.; Pintado, M. Impact of whey protein coating incorporated with Bifidobacterium and Lactobacillus on sliced ham properties. Meat Science 2018, 139, 125133, http://doi.org/10.1016/j.meatsci.2018.01.016.

26. AOAC. Association of Official Agricultural Chemists. Official methods ofanalysis (15th ed.). 1990. 
27. de Camargo, A.C.; Vidal, C.M.M.; Canniatti-Brazaca, S.G.; Shahidi, F. Fortification of Cookies with Peanut Skins: Effects on the Composition, Polyphenols, Antioxidant Properties, and Sensory Quality. J. Agric. Food Chem 2014, 62, 11228-11235, http://doi.org/10.1021/jf503625p.

28. Secretaría de salud. Preparación y dilución de muestras de alimentos para su análisis microbiológico. Norma Oficial Mexicana nom-110-ssa1-1994, Bienes y servicios 1995. Available online: http://www.salud.gob.mx/unidades/cdi/nom/110ssa14.html (accessed on 10 May 2021).

29. Secretaría de salud. Método para la cuenta de bacterias aerobias en placa. Norma oficial mexicana nom092-ssa1-1994, bienes y servicios 1995. Available online: http://www.dof.gob.mx/nota_detalle.php?codigo=4886029\&fecha=12/12/1995 (accessed on 10 May 2021).

30. Secretaría de salud. Método para la cuenta de microorganismos coliformes totales en placa. Norma oficial mexicana nom-113-ssa1-1994, bienes y servicios 1995. Available online: http://salud.gob.mx/unidades/cdi/nom/113ssa14.html (accessed on 10 May 2021).

31. Secretaría de salud. Método para la cuenta de mohos y levaduras en alimentos. Norma oficial mexicana nom111-ssa1-1994, bienes y servicios 1995. Available online: http://dof.gob.mx/nota_detalle.php?codigo=4881226\&fecha=13/09/1995 (accessed on 10 May 2021).

32. Secretaría de salud. Cereales y sus productos. Harinas de cereales, sémolas o semolinas. Alimentos a base de cereales, de semillas comestibles, harinas, sémolas o semolinas o sus mezclas. Productos de panificación. Disposiciones y especificaciones sanitarias y nutrimentales. Norma oficial mexicana nom-147-ssa1-1996, bienes y servicios 1999. Available online: http://legismex.mty.itesm.mx/normas/ssa1/ssa1147.pdf (accessed on 10 May 2021).

33. da Silva, T.F.; Conti-Silva, A.C. Potentiality of gluten-free chocolate cookies with added inulin/oligofructose: Chemical, physical and sensory characterization. LWT 2018, 90, 172-179, http://doi.org/10.1016/j.lwt.2017.12.031.

34. Colla, K.; Costanzo, A.; Gamlath, S. Fat Replacers in Baked Food Products. Foods 2018, 7 , http://doi.org/10.3390/foods7120192.

35. Blanco Canalis, M.S.; León, A.E.; Ribotta, P.D. Incorporation of dietary fiber on the cookie dough. Effects on thermal properties and water availability. Food Chemistry 2019, 271, 309-317, http://doi.org/10.1016/j.foodchem.2018.07.146.

36. Çelik, E.E. \& Gökmen, V. Formation of Maillard reaction products in bread crust-like model system made of different whole cereal flours. European Food Research and Technology 2020, 246, 1207-1218, https://doi.org/10.1007/s00217-020-03481-4.

37. Paciulli, M.; Littardi, P.; Carini, E.; Paradiso, V.M.; Castellino, M.; Chiavaro, E. Inulin-based emulsion filled gel as fat replacer in shortbread cookies: Effects during storage. LWT 2020, 133, https://doi.org/10.1016/j.lwt.2020.109888.

38. Giménez-Bastida, J.A.; Piskuła, M.; Zieliński, H. Recent advances in development of gluten-free buckwheat products. Trends in Food Science \& Technology 2015, 44, 58-65, http://doi.org/10.1016/j.tifs.2015.02.013.

39. Orozco-Parra, J.; Mejía, C.M.; Villa, C.C. Development of a bioactive synbiotic edible film based on cassava starch, inulin, and Lactobacillus casei. Food Hydrocolloids 2020, 104, 105754, http://doi.org/10.1016/j.foodhyd.2020.105754.

40. Mancebo, C.M.; Picón, J.; Gómez, M. Effect of flour properties on the quality characteristics of gluten free sugar snap cookies. LWT - Food Science and Technology 2015, 64, 264-269, http://doi.org/10.1016/j.lwt.2015.05.057.

41. Huda, M.N.; Lu, S.; Jahan, T.; Ding, M.; Jha, R.; Zhang, K.; Zhang, W.; Georgiev, M.I.; Park, S.U.; Zhou, M. Treasure from garden: Bioactive compounds of buckwheat. Food Chemistry 2021, 335, http://doi.org/10.1016/j.foodchem.2020.127653.

42. Yang, H.; Sun, Y.; Cai, R.; Chen, Y.; Gu, B. The impact of dietary fiber and probiotics in infectious diseases. Microbial Pathogenesis 2020, 140, http://doi.org/10.1016/j.micpath.2019.103931.

43. Isuiza, G.G.P.; Perez, J.F.L.; Sánchez, I.A.C.; Olano, J.C.; Valerio, W.F.S.; Delgado, L.F.M. Vida en anaquel de galletas saladas utilizando pruebas aceleradas. Anales Científicos 2018, 79, 218-225, http://dx.doi.org/10.21704/ac.v79i1.1166.

44. Sakač, M.; Pestorić, M.; Mandić, A.; Mišan, A.; Nedeljković, N.; Jambrec, D.; Jovanov, P.; Lazić, V.; Pezo, L.; Sedej, I. Shelf-life prediction of gluten-free rice-buckwheat cookies. Journal of Cereal Science 2016, 69, 336-343, http://doi.org/10.1016/j.jcs.2016.04.008. 